\title{
DIREITO A IMAGEM DE PESSOAS PÚBLICAS VERSUS LIBERDADE DE EXPRESSÃO DE IMPRENSA: UMA ANÁLISE A LUZ DO DIREITO CONSTITUCIONAL
}

\section{ARTIGO ORIGINAL}

NETO, Luiz Gonzaga ${ }^{1}$

NETO, Luiz Gonzaga. Direito A Imagem De Pessoas Públicas versus Liberdade De Expressão De Imprensa: Uma análise a luz do Direito Constitucional. Revista Científica Multidisciplinar Núcleo do Conhecimento. Ano 05, Ed. 01, Vol. 08, pp. 15 48. Janeiro de 2020. ISSN: 2448-0959, Link de acesso: https://www.nucleodoconhecimento.com.br/lei/direito-a-imagem

\section{RESUMO}

O presente trabalho tem como escopo a análise dos limites da liberdade de expressão quando confrontados com os do direito de imagem, bem como suas consequências na vida de pessoas públicas e seus reflexos nas decisões dos tribunais superiores sob a ótica do direito constitucional. A finalidade do artigo científico em tela é contrapor tais direitos fundamentais para ponderar qual deve ser preterido no caso concreto. A internet oportuniza uma ampla liberdade para que o indivíduo possa se expressar da forma que entender sobre todo e qualquer assunto do seu interesse. Porém, diante do avanço digital, o Ordenamento Jurídico nem sempre consegue acompanhar esse desenvolvimento e por muitas vezes se depara com situações nas quais direitos fundamentais entram em conflito, sendo necessário a escolha pela prevalência de um deles, visando dar efetividade a uma garantia essencialmente constitucional. A proteção conferida para que as pessoas expressem sua opinião pode sofrer restrições quando o assunto em pauta é a vida íntima de artistas, já que esses, como sujeitos de direitos que são, estão protegidos pelo direito à imagem, ganhando relevância em um cenário jurídico onde a pessoa humana ocupa o posto central. Ainda, busca-se

\footnotetext{
${ }^{1}$ Mestrando e pós-graduado em Direito do Trabalho pela PUC-SP.
} 
analisar a evolução histórica da Imprensa até o contexto atual de liberdade de expressão, verificando como esse direito pode interferir na esfera privada do indivíduo.

Palavras-chave: liberdade de expressão, direto à imagem, conflitos entre Direitos Fundamentais, pessoas públicas.

\section{INTRODUÇÃO}

O presente artigo trata-se de uma análise acerca do conflito entre a liberdade de expressão e o direito à imagem na tutela de direitos de pessoas públicas - as celebridades - abordando situações práticas onde a Jurisprudência encontra-se dividida na defesa de direitos igualmente fundamentais.

Tendo em vista ser a liberdade de expressão ser o direito do ser humano de manifestar seu pensamento, opinião, atividade intelectual, artística, cientifica e de comunicação, bem como o tratado na Constituição Federal brasileira em seu artigo $5^{\circ}$ onde assegura tal direito e o põe como elemento fundamental de uma sociedade democrática embasada pela igualdade e liberdade, mister estudar o uso inconsequente e desarrazoado desse direito e as graves complicações de cunho pessoal e profissional para pessoas públicas.

O direito à imagem é um direito de personalidade e encontra amparo na Constituição Federal (art. 5을 incisos V, X e XXVII). Por ser corolário do princípio da dignidade da pessoa humana, é inegável que esta e a sua proteção tornaram-se o centro maior do ordenamento jurídico, tendo saliente importância para artistas que temem em ter divulgados detalhes íntimos de sua vida privada.

$\mathrm{O}$ avanço da internet coaduna-se com a fragilidade da imagem, que é vista e descartada em poucos segundos pela rede mundial de computadores, hoje abrangendo ainda tablets, smartphone e laptops. Uma imagem pode tanto alçar a pessoa pública a status de herói como entregá-la ao escárnio da opinião popular, criando uma verdadeira novela da vida real. 
No capítulo 2 (dois) trataremos sobre como a imprensa, principal usuário da liberdade de expressão, surgiu no território nacional. Os pontos de partida, as inspirações e as influências foram muitas até o início da Segunda Grande Guerra, quando a televisão e o rádio adentraram numa seara que era essencialmente dos jornais. $\mathrm{O}$ advento da Lei $n^{\circ} 5.320 / 67$ ou Lei de Imprensa também figurou como marco histórico, pois em plena ditadura militar, a opressão da liberdade de se expressar, pautada pelo Ato Institucional $n^{\circ} 5$ - Al5, colocou a imprensa no talvez maior imbróglio de sua história. O último marco interruptivo ocorreu com o surgimento da Internet, quando a imprensa tomou proporções ilimitadas e se tornou protagonista da globalização.

No capítulo 3, a abordagem versa sobre a origem da liberdade de expressão e o papel da imprensa como legitimada ao uso deste direito, bem como os dispositivos legais que asseguram essa garantia. Também é exposta a trajetória que a liberdade de expressão trilhou até ganhar status de Direito Fundamental na Constituição Federal de 1988 e a interpretação do Supremo Tribunal Federal acerca do uso deste direito de forma individual por meio de sua Jurisprudência.Com o progresso avassalador das mídias sociais, a tutela destes direitos ganhou notória visibilidade, já que o público antes restrito a programas de celebridades e revistas de fofoca, passa a ter acesso a vida íntima do famoso por meio de aplicativos digitais onde o próprio se expõe, tornando bastante tênue a linha que separa a vida pessoal da vida profissional e o que deve ou não ser exposto.

No último capítulo, versar-se-á sobre casos reais em que ocorreram conflitos entre o direito de imagem e a liberdade de expressão e a forma como os Tribunais brasileiros se posicionaram perante tal situação. Questão importante também envolve o direito de imagem do nascituro, abordado neste capítulo pelo caso envolvendo o apresentador Rafinha Bastos e a cantora Wanessa Camargo, quando ainda estava grávida de seu filho. Também analisaremos de forma sintética os casos envolvendo crimes de internet, como o da atriz Carolina Dieckmann, que inspirou a criação de uma Lei para regulamentar tais crimes, bem como o de outros artistas que tiveram sua intimidade violada pela liberdade da imprensa. Por fim, falaremos de um dos poucos 
casos envolvendo direito de imagem que chegou a mais alta Corte do nosso país, de autoria da atriz brasileira Cássia Kis.

\section{TRAJETÓRIA HISTÓRICA DA IMPRENSA NA HISTÓRIA DA HUMANIDADE E TERRITÓRIO PÁTRIO}

O surgimento da escrita, ainda como pictografia, surgiu na Mesopotâmia, retratando um objeto ou um ser, logo se exigindo do homem a capacidade de interpretar o que estava vendo na imagem, originando-se a necessidade de se comunicar por meio de palavras, tornando-se uma forma eficaz e permanente de conviver em sociedade.

Não obstante, nesta linha gradativa, até a evolução da linguagem falada para a linguagem escrita, foi necessário um "tsunami" de fatores econômicos, "como um sistema de controle de contabilidade dos bens trocados" (SOUSA, 2003, p. 145).

Em Atenas, nasceram os primeiros traços dos movimentos democráticos e de exposição de ideias. Tais movimentos ocorriam quando os cidadãos atenienses, sem ter noção de que estavam adentrando no universo democrático, se uniam para discutir política, trocando informações e ideais.

De acordo com Habermas (1984 apudSOUSA, 2003), o espaço público surgiu no seio da democracia ateniense, mas foi no século XVIII que o concreto se firmou na versão da era moderna. A imprensa foi a primeira a moderar as discussões nesses espaços públicos.

Todavia, o marco do nascimento da imprensa no mundo foi o surgimento da impressora, que culminou na reprodução de informações. Sousa (2003) aduz que, o que fez eclodir meios de comunicação foram os grandes descobrimentos, o crescimento do comércio e a invenção da tipografia. Porém, foi a junção de três tipos de impressos - gazetas, pasquins e libelos - que deram origem ao o jornalismo, enaltecendo o papel da imprensa na sociedade civil. Ele também preleciona que o surgimento da imprensa foi o primeiro passo para a democratização da cultura, asseverando que o sucesso só ocorreu em função do aperfeiçoamento contínuo das 
técnicas de tipografia, a diminuição dos custos e o aumento das tiragens de jornais, além, é claro, da necessidade que se tornara cada vez mais presente no ser humano de tomar conhecimento acerca dos acontecimentos. A chegada do século XIX trouxe uma imprensa de partido, extremamente política e parcial, que falava exclusivamente sobre interesses partidários e demonstrava o alto grau de politização da população. Ademais, era cristalina a falta de notícias factuais aptas a serem disseminadas. Porém, no mesmo século, surgiram os primeiros jornais factuais, nos Estados Unidos, que retiravam as notícias do meio político e adentravam no cotidiano da sociedade (SODRÉ, 1994). Importante destacar que, no Brasil, a imprensa surge no contexto do descobrimento do país por Portugal e consequente colonização. A leitura era inicialmente restrita aos religiosos, que podiam ler a bíblia. A Igreja tinha papel importante, já que seus padres davam avisos de fatos significativos ou até mesmo advertências à população no meio dos sermões. Ocorre que só em 1808 a imprensa se estabeleceu de forma definitiva no país, com a Impressão Régia. O Correio Brasiliense, editado por Hipólito da Costa na capital da Inglaterra, fez emergir a crítica ao poder Real. Esse veículo apontava os defeitos da gestão do nosso país e foi o primeiro modo de crítica à Administração Pública.

Nos últimos anos deste século, os jornais ficaram mais acessíveis e direcionados à população, surgindo a figura do sensacionalismo e a necessidade desmedida em lucrar com uma notícia que não seja coberta pelo manto da relevância social, até chegar à atualidade, onde as manchetes de jornais podem ser, por exemplo, a ida de uma atriz famosa até a padaria.

Com a Segunda Grande Guerra, a televisão e o rádio passaram a ocupar um lugar que também era dos jornais, dividindo atenções entre uma população que não mais queria estar excluída do que acontecia no mundo (FERREIRA FILHO, 1979). O surgimento da Internet aparece como marco interruptivo da história da Imprensa, colocando o mundo em conexão por uma rede de computadores. Nota-se o início da a expansão da imprensa, sem a devida noção do alcance que teria nos dias de hoje, onde é possível o rápido acesso a informação por dispositivos móveis, a qualquer 
hora, de forma gratuita, e em qualquer lugar do mundo. Pollyana Ferrari (2003. p. 125), em acertada lição, garante:

Não se pode negar que a Internet proporcionou um acesso á informação de maneira única. Achar o endereço de um restaurante sem ter que perguntar para ninguém, usar o telefone ou folhear a lista telefônica, (...) Enfim, a abrangência de serviços oferecidos num portal consegue preencher e resolver grande parte das necessidades do moderno. (FERRARI, 2003. p. 248).

\subsection{SURGIMENTO DA LEI DE IMPRENSA NO CENÁRIO NACIONAL}

A Lei $n^{\circ}$ 5.230/67 - Lei de Imprensa surgiu em um período onde as liberdades individuais achavam-se mitigadas, tendo em 2009 sido declarada sua não receptação pela Constituição de 1988 em sua integralidade[2]. Antes desse ato, a referida Lei serviu de mecanismo para reprimir a liberdade de expressão, desde sua promulgação, em 1967. Usando seu texto como fundamento, inúmeros atos de censura foram cometidos, dificultando em larga escala o trabalho da imprensa no Brasil.

Importante dissertar sobre a historicidade da Lei, principalmente no que tange ao momento de sua promulgação. Afinal, a maioria dos votos dos ministros pela nãorecepção da referida, foram embasados no pensamento da época de sua publicação.

Durante a ditadura militar, mais precisamente em 10 de março de 1967, foi ratificada a Lei de Imprensa, após publicação no Diário Oficial da União, no dia 10 de fevereiro de 1967. Nessa época, o país era governado pelo Presidente Castello Branco, tendo assumindo o encargo em caráter provisório, em que pese por um período suficiente para reestruturar a estabilidade e o sistema democrático. Esse governo era pouco democrático, culminando no desenvolvimento de uma doutrina de segurança nacional avançada (FERREIRA FILHO, 1979). É com base na figura da segurança nacional que surge a Lei de Imprensa, permanecendo fortalecida no mandato do Presidente Costa e Silva, de 1967 a 1969, ganhando força até os dias de hoje, ou mais especificamente, até o dia 30 de abril de 2009, quando é declarada sua não-recepção 
pela nossa Carta Magna. Esse período da promulgação é ligado ao pensamento repressor de que era necessário um instrumento para defender o governo contra a subversão. Ou seja, deveriam ser impostos limites à imprensa para que esta não pudesse falar o que quisesse ou o que pensasse, ou até mesmo para que essa imprensa não publicasse a verdade, que, naquela época, poderia consubstanciar-se no medo generalizado e a insatisfação da população. Mais do que a defesa da subversão, o governo queria a não-publicização dos seus atos, evitando a reprimenda daqueles que já estavam demasiadamente horrorizados.

Exatamente cinco dias após a promulgação da Lei, é empossado o General Arthur Costa e Silva e, dentro dos 21 anos de terror da História Brasileira, se dissemina a Lei de Imprensa, impedindo a comunicação daqueles que a conquistariam, logo depois, no status de direito fundamental.

Perante esse cenário de proibição, verificaram-se diversas situações no sentido de burlar a censura e os limites impostos pela Lei de Imprensa, como, por exemplo, a impressão de receitas de bolo nos espaços destinados a textos que sofriam censura e, desta forma, não podiam ser publicados. Ainda, merece referência, as músicas eivadas de metáforas e críticas ao governo.

Com a Lei de Imprensa, houve a estabilização da censura, que, além de interferir em matérias de jornais e revista, acabou por adentrar na ficção, sendo a dramaturgia alvo da Divisão de Censuras de Diversões Públicas da Polícia Federal, que cortava textos, proibia determinados assuntos, censurava cenas, capítulos, e até novelas inteiras.

Exemplo clássico ocorreu no ano de 1987, quando a divisão buscou proibir o aparecimento das nádegas de um homem na novela da Rede Globo "Brega e Chique", do autor Cassiano Gabus Mendes. Naquela oportunidade, logo na abertura da trama, aparecia um modelo percorrendo sem roupa um cenário escuro, em clara alusão aos períodos vivenciados pelo país durante a ditadura militar e, por exigência da censura, as nádegas do modelo ganharam uma folha de parreira como coberta. Todavia, ainda não satisfeita, houve determinação pela retirada da cena da abertura da novela. Nesta época, estando o país em plena redemocratização e, com a promulgação da 
Constituição de 1988, a censura passou a ser proibida. Urge aclarar que o próprio Ministro da Justiça desautorizou a divisão de censura e, na situação mencionada anteriormente, liberou as nádegas do modelo na abertura da novela. Era o fim da censura. Todavia, a Lei de Imprensa subsistiria alguns anos.

\subsection{BREVES COMENTÁRIOS SOBRE O ATO INSTITUCIONAL № 5}

O Ato Institucional $\mathrm{n}^{\circ} 5$, com data marco de 13 de dezembro de 1968, foi uma das maiores marcas de expressão da ditadura militar brasileira. O governo era a do general Costa e Silva, tendo sido responsável pela produção de uma gama de ações arbitrárias com efeitos duradouros, tendo inclusive concedido poder de exceção aos governantes, que poderiam punir da forma mais arbitrária possível os que expressassem pensamentos ou ideologias contrárias.

"O ano que não terminou" (VENTURA, 2006. p. 307) como ficou conhecido 1968, ficou caracterizado por um momento de contestação da política nacional, onde os estudantes protestavam contra a política tradicional e suplicavam por uma liberdade até então desconhecida. No decorrer do referido ano, houve uma intensificação de protestos contra o regime ditatorial e, em contrapartida, o governo acabou por providenciar atos instrumentais mais sofisticados para se sobrepor.

Nesse mesmo ano, a Igreja "toma para si" a defesa dos direitos humanos, passando os líderes políticos vítimas da cassação a se associar com o escopo de dar somar na política nacional, combatendo a ditadura.

A primeira greve operária desde o início do regime militar foi deflagrada por um grupo de metalúrgicos da cidade de Osasco/SP, gerando nos governantes uma necessidade de tratar com mais rigor os movimentos sociais, dotados de medidas enérgicas e duras, sobretudo para aqueles que se mostrassem descontentes com o modo de administração.

A promulgação do Ato Institucional $n^{\circ} 5$ teve como influência o "conselho" que o Deputado Márcio Moreira Alves, do Movimento Democrático Brasileiro (MDB), que as pessoas não participassem dos desfiles militares do 7 de setembro, como para que 
as mulheres que falassem em liberdade declinassem o convite de sair com os oficiais[3]. Na mesma data, outro Deputado do mesmo partido, Hermano Alves, redigiu inúmeros artigos no Jornal "Correio da Manhã" que foram considerados pelos militares como provocação e, por meio do governo, tendo sido requerido a cassação dos mandatos dos Deputados ao Congresso.

Em um ato de autoridade, por diferença de 75 votos, o requerimento para cassação foi julgado improcedente pelo Congresso, sendo no dia seguinte, promulgado o Al-5, autorizando o Presidente da República, de forma excepcional, e sem carecer de análise judicial, ordenar recesso no Congresso Nacional, intervir da maneira que the for oportuna e conveniente nos estados e municípios, cassar mandatos de parlamentares, suspender os direitos políticos de qualquer cidadão por dez anos, baixar decreto autorizando o confisco de bens tidos como ilícitos; fazer a suspensão da garantia do habeas corpus, dentre outros[4].

Em seu preâmbulo, o Ato Institucional $n^{\circ} 5$, alegava que tal medida era uma necessidade para atingir o escopo da revolução, "com vistas a encontrar os meios indispensáveis para a obra de reconstrução econômica, financeira e moral do país" (COSTA, 2013. p. 211).

Como primeira consequência do ato, foi decretado recesso no Congresso Nacional por tempo não determinado. Mais de dez Deputados Federais tiveram seus mandatos cassados, dentre eles Hermano Alves e Márcio Moreira Alves. A cassação alcançou proporções tão grandes que até Ministros do Supremo Tribunal Federal foram vitimados.

Com o fortalecimento das formas de repressão, a imprensa era submetida à retaliações. Maria Aparecida de Aquino (1999), renomada historiadora brasileira, lembra que as duas formas de censura presentes nos meios de comunicação a partir do ano de 1968 eram as de ligações para os jornais, visando ordenar aquilo que seria autorizado ou não para ser veiculado, e a outra, mais rígida, era chamada de censura prévia, consistindo em censores infiltrados nas redações, indicando o que deveria ou não ser impresso. 
O processo gerou consequências também na imprensa alternativa, como o jornal 'o São Paulo', que integrava a cúria metropolitana, tendo sido os jornais mais vitimados a Tribuna de Imprensa, O Estado de São Paulo e Veja, segundo a historiadora no livro Censura, Imprensa e Estado autoritário (1968-1978).

O Al-5, durante os dez anos em que vigorou, atingiu 273 mandatos parlamentares, foi acionado 579 vezes, punindo 142 militares, 145 funcionários públicos civis, 102 policiais, 28 funcionários do Poder Judiciário. Foi instrumento para banimento de 80 oposicionistas do regime e para intervenção em 10 municípios. (ELIAS, 2013. p. 184).

\section{COMENTÁRIOS ACERCA DA ORIGEM DA LIBERDADE DE EXPRESSÃO E SUA EVOLUÇÃO}

O pensamento é algo que coexiste no âmbito interno do indivíduo, sendo mesmo intrínseco a ele. Neste, não cabe ao Direito intervir ou controlar, pois encontra-se na esfera pessoal e privada de todo e qualquer ser humano. Porém, quando esse pensamento ultrapassa o foro íntimo é que se faz necessário um ordenamento jurídico limitador e fiscalizador. Foi destacado que é:

Preciso distinguir duas faces da liberdade de pensamento: a de consciência e a liberdade de expressão. A primeira é de foro íntimo e enquanto não manifesta, é condicionável por vários meios. Ainda assim continua sendo livre, já que ninguém poderá ser obrigado a pensar deste ou daquele modo. Segundo a Constituição Federal de 1988, essa liberdade de crença e de consciência é inviolável. (FERREIRA FILHO, 1984. p. 266).

A liberdade de expressão é a materialização do pensamento do indivíduo, que pode se dar em conversas com amigos, familiares, no trabalho, na faculdade, nos bares, na universidade, em qualquer lugar onde haja pessoas dispostas a ouvir e debater ideias que podem ser convergentes ou não sobre determinada situação, coisa ou pessoa. 
Contudo, dentre os inúmeros personagens que podem manifestar sua expressão e falar o que tem vontade, sobre o que tem vontade, cabe à imprensa ser a protagonista deste direito fundamental.

A imprensa vive da liberdade de expressão e da manifestação que nem sempre é bem aceita pelos personagens expostos. Do mesmo modo que a manifestação do pensamento é involuntária, a necessidade e vontade de estar a par do que acontece no mundo é latente desde o início dos tempos, ganhando seu maior destaque com a virtual.

O parecer 27/X da Câmara Corporativa de Portugal, elaborado sobre a Lei de Imprensa do país, fala que:

A necessidade de informação é inata no homem, pois desde os primórdios da civilização quer saber o que ocorre à sua volta: "Desde os primeiros passos que se deram para a transmissão de informações (sinalização à vista, aviso sonoro, mensageiros a pé, dos quais ficou célebre o soldado de Maratona, os correios a cavalo, as anilhas nos pombos correios) até as comunicações por satélites que transmitem palavras e imagens a distância que podem, com toda a propriedade, considerar-se astronômicas, como é longo o caminho percorrido no sentido da generalização e democratização da informação! Ela interessa a todos, visto que ninguém pode alimentar a pretensão de conhecer diretamente os fatos sobre os quais tem necessidade de formar um juízo (DIÁRIO DAS SESSÕES, 1971 apud DENARDI, 2011. p. 143).

A liberdade de pensamento é a outorga de uma permissão de livre manifestação feita a toda e qualquer pessoa, independente de leis e regras estipuladas pelo ordenamento jurídico. O longo processo até se tornar positivo e institucionalizado, fez o direito de expressão acompanhar a transformação dos direitos do homem, até ganhar o status de direito fundamental que hoje o tem. 
Trata-se de um direito fundamental garantido pela Constituição Federal. Antes de tecer comentários mais aprofundados sobre a liberdade de expressão vista por um status de direito fundamental, importante se faz explanar a diferença de direitos fundamentais e direitos humanos, evitando qualquer confusão que possa existir entre esses dois institutos, como ensinado por Bonavides (2004):

A primeira questão que se levanta com respeito à teoria dos direitos fundamentais é a seguinte: podem as expressões direitos humanos, direitos do homem e direitos fundamentais ser usadas indiferentemente. Temos visto nesse tocante o uso promiscuo de tais denominações na literatura jurídica, ocorrendo, porém o emprego mais frequente de direitos humanos e direitos do homem entre os autores angloamericanos e latinos, em coerência aliás com a tradição e a história, enquanto a expressão direitos fundamental parece ficar circunscrita à preferência dos publicistas alemães. (BONAVIDES, 2004 apud VALENTINO, 2012. p. 808).

Em razão da democracia ser um regime que cultiva a autodireção política do ser na sociedade, é razoável que sua eficácia só seja alcançada quando qualquer cidadão tiver acesso livre e fácil às informações, para que possam tornar-se cientes e conscientes da atualidade do país e do mundo como um todo, em seu âmbito econômico, cultural e político, sendo imprescindível que o indivíduo tenha ciência do que acontece ao seu redor, para assim, formar sua opinião e expressar, de forma livre e participativa, seu modo de pensar.

\subsection{A LIBERDADE DE EXPRESSÃO COMO DIREITO FUNDAMENTAL}

Os direitos fundamentais são direitos essenciais a todo e qualquer cidadão, sendo inerentes à pessoa humana. Eles surgiram como:

O conjunto institucionalizado de direitos e garantias do ser humano que tem por finalidade básica o respeito a sua dignidade, por meio de sua proteção contra o arbítrio do poder estatal e o estabelecimento de 
condições mínimas de vida e o desenvolvimento de personalidade humana (MORAES, 2003. p. 326).

Em função de serem correlatos à pessoa humana e pelo seu patamar privilegiado em relação a outros direitos, a doutrina e jurisprudência apontam como suas características a imprescritibilidade, irrenunciabilidade, inviolabilidade, inalienabilidade, universalidade, efetividade, efetividade, interdependência e complementariedade.

No Estado Democrático de Direito a garantia da liberdade de expressão está na Constituição Federal de 1988 em seu artigo 5', intitulado de 'Dos Direitos e Garantias Fundamentais'. Nesse artigo estão reunidos os pilares mais importantes para fácil compreensão do tema:

(...) IV - é livre a manifestação do pensamento, sendo vedado o anonimato;

IX - é livre a expressão de atividade intelectual, artística científica e de comunicação, independente de censura ou licença

X - são invioláveis a intimidade, a vida privada, a honra e a imagem das pessoas, assegurado o direito a indenização pelo dano material ou moral decorrente de sua violação;

XLI - a lei punirá qualquer discriminação atentatória dos direitos e liberdades fundamentais; (...)

A liberdade de expressão é um direito que surgiu ulteriormente ao nascimento do Estado Liberal, como resultado de um projeto político inspirado na independência americana e na Revolução Francesa. Assim, corresponde a nada menos que a inserção de qualquer pessoa perante o Estado, tomando como base sua afirmação, e tendo como conteúdo única e exclusivamente suas ideias. Por ter previsão constitucional, cabe ao Estado garantir o exercício de tal direito fundamental (LIMA, 2012). 
Não obstante, sua materialidade só se torna possível na ausência de censura, e ocorre por meio de opiniões que nem sempre serão bem aceitas e vistas pelas pessoas que estão "em pauta". Segundo Lima (2012. p. 546), no Brasil, o mais abrangente princípio constitucional que deve ser invocado para garantir o direito de se comunicar, é o da liberdade de expressão. Isso significa que a todos deve ser cedido o direito de participar de forma ativa de debates com ideias plurais e divergentes, visando o adequado funcionamento da democracia.

É uma faculdade dada a todos os brasileiros de se manifestar e opinar sobre os temas em pauta no país e no mundo. Neste diapasão, relacionando o valor da liberdade de expressão com os objetivos sociais da coletividade, Farias (2004) aduz que:

Rui Barbosa já apregoava o benefício da transparência luminosa que aquela liberdade poderia propiciar à higiene dos costumes públicos e à profilaxia dos abusos que estão passando na esfera pública. Mais recentemente, Aluízio Ferreira alude à dramática necessidade do acesso de todos ao conhecimento (ideias e informações) para o estabelecimento de uma autêntica convivência democrática na atual sociedade da comunicação (FARIAS, 2004. p. 137).

As profissões embasadas pela comunicação social apresentaram avanços significativos na troca de informações entre indivíduos. A partir do momento em que a divulgação das notícias se inicia, a consequência mais visível é os atores sociais se tornarem consumidores ávidos por informação. Consumidores em potencial que começam a ser um risco para a salutar liberdade de expressão.

Com a globalização e o avanço da comunicação virtual, a liberdade de expressão passa a ser garantidor do direito de uma imprensa ligeira e minuciosa. A cada segundo surgem mais e mais notícias e, na vontade insaciável de produzir conteúdo, pautas que não teriam tanta relevância acabam se tornando manchetes de jornais. A vida íntima de atores, apresentadores, cantores e até políticos são entregues ao escárnio da opinião pública. 
É comum ver em capas de revistas anúncios de separação de casais famosos, bastidores da saída de um componente de banda conhecida ou até detalhamento do que determinado artista fez ou deixou de fazer em uma festa de lançamento de novelas. Também não é raro encontrar fotos de um deputado com sua nova namorada ou o valor que deu a conta do restaurante do Presidente da Câmara. Descortina-se situação em que a privacidade e o direito a imagem se encontram em confronto direto com a liberdade de expressão.

Como ilustração ao contexto traçado anteriormente, salutar narrar fato ocorrido nos idos de 2014, quando a Grazi Massafera foi a principal personagem de uma novela da vida real envolvendo seu casamento com o também ator Cauã Reymond. Ao se dirigir à paróquia de sua igreja, no centro do Rio de Janeiro, Massafera conversou com um fotógrafo que a seguia e pediu respeito em não a fotografar dentro da igreja. Ingênua, respondeu a inúmeras perguntas do fotógrafo sobre sua vida pessoal, acreditando estar numa conversa informal, e inclusive numa delas, assume que seu ex-marido estaria se relacionando com a atriz Isis Valverde, apontada como pivô do término da relação. Grazi estava sendo filmada às escondidas e toda sua conversa foi gravada e publicada no portal Terra, no mesmo dia, se tornando, em menos de 3h, o assunto mais lido da internet. A atriz cogitou processar o portal alegando ofensa a seu direito fundamental de proteção à imagem. Em sua defesa, o portal alegou está amparado por um direito igualmente fundamental, o da liberdade de expressão, porém, em razão de acordo firmado com a atriz deletou o vídeo, que já tinha mais de 2 milhões de visualizações.

Ainda como exemplo, a esposa do Sr. Eduardo Cunha, Presidente da Câmara dos Deputados, também foi vítima do uso da liberdade de expressão da imprensa, que divulgou que em meio a crise econômica do país e as acusações de corrupção envolvendo o político, que a mesma estaria almoçando em um dos mais caros restaurantes do país: o Fasano. A liberdade de expressão da imprensa especializada, visivelmente interessada em denegrir ainda mais a imagem do peemedebista, se confrontou mais uma vez com o direito fundamental à privacidade e à imagem da Sra. Cunha que, apesar de casada com um dos homens mais importantes do país, 
trabalhou por mais de duas décadas como âncora de jornais da TV Globo, recebendo um dos mais altos salários da casa.

\subsection{A LIBERDADE DE EXPRESSÃO À LUZ DAS DECISÕES DO SUPREMO TRIBUNAL FEDERAL}

A liberdade de expressão não tem alta relevância apenas pelo fato de achar-se expresso em nosso Diploma Constitucional, com status de direito fundamental, mas também atua com notório protagonismo nas decisões da mais alta Corte do nosso país. Alguns casos merecem plausível análise, onde o Tribunal demonstra de forma cristalina, seu embasamento constitucional.

Caso célebre é o do julgamento do HC 82424, ou caso "Siegfried Ellwanger". O réu foi acusado pelo crime de racismo contra o povo judeu, tendo sido absolvido em primeira instância. O Tribunal de Justiça do Rio Grande do Sul reformou a decisão e condenou Siegfried Ellwanger por fazer apologia ao preconceito e à discriminação. Por meio do Habeas Corpus, o caso chegou ao Superior Tribunal Federal (STF), quando o réu - ora impetrante, alegou que não houve qualquer prática de delito racial, já que os judeus são um povo e não uma raça. No mérito, o que se versou sobre a liberdade de expressão foi que:

Apesar de constituir pedra angular do próprio sistema democrático, revelar-se um dos mais efetivos instrumentos de controle do próprio Estado, e ser, igualmente, elemento essencial da própria formação da consciência e de vontade popular, não se the pode atribuir primazia absoluta no contexto de uma sociedade pluralista, em razão de valores outros, como os da igualdade e da dignidade humana. Exclui-se do âmbito de proteção da liberdade de expressão o estímulo à intolerância e ao ódio público pelos judeus. Não é a liberdade de expressão um direito absoluto, pois sofre limitações de natureza ética e de caráter jurídico. Nesse sentido, a conduta do Paciente foi sim subsumida pelo ilícito da prática do racismo, pois preconceituosa, odiosa, hostil ao povo 
judeu, constituindo crime inafiançável e imprescritível. A Constituição, por certo, a priori, veda a censura, mas não imuniza a responsabilidade civil ou penal, pelo que foi expresso ou dito (CRUZ, 2010. p. 515).

Importante registrar a opinião de Canotilho e Machado (2003 apud CRUZ, 2010. p. 674.) que admitem que a liberdade de expressão em sentido amplo se constitui pela liberdade de expressão em sentido estrito, a liberdade de informação, a liberdade de imprensa, os direitos dos jornalistas e da liberdade de radiofusão.

Outro caso que merece destaque é o RE 5119611, também conhecido nacionalmente como "Dispensabilidade do Diploma para a Profissão de Jornalista". Nesta situação, foi discutido pela Suprema Corte se era necessário ou não que o jornalista fosse detentor de diploma para exercer a profissão de jornalista regularmente.

Com o avanço das redes sociais e multiplicação diária dos sites de notícias, qualquer pessoa que esteja munida de um computador ou smartphone pode ser jornalista, blogueiro, colunista ou fazer sua carta de opinião. No mérito, ao tergiversar sobre a liberdade de expressão, o autor Cruz (2010. p. 136) falou que o "Estado Constitucional contribuiu para a estruturação da sociedade com liberdade comunicativa". Suscitou também que:

A informação plena proporciona a maturidade intelectual para ponderar as opiniões diversas, e inclusive contrapostas, situação que se adapta ao ideal constitucional-democrático da livre circulação de informações e ideias. É esse o aspecto que rubrica a liberdade/direito de informação como um objetivo político da democracia. (...) O titular de tal liberdade é a coletividade, cada um de seus membros e, em relação à sua estrutura, pode-se dizer que forma parte das liberdades positivas ou direitos de prestação. Configura-se desde uma ambivalente perspectiva de proteção: por um lado, uma prestação positiva, de receber e de difundir a informação na medida em que seja veraz e publicamente relevante; por outro, a negativa, de proibir os impedimentos desarrazoáveis que possam afetar a efetiva divulgação da notícia (CRUZ, 2010. p. 137). 
Por fim, explanou que o direito de transmitir informação não pode ser privilégio só dos profissionais da informação, e sim de todos os que o façam pelos caminhos normais e regulares de formação da opinião pública.

O Supremo Tribunal também se pronunciou em caso de incidência da liberdade de expressão nas decisões do STF é a ADPF 130[5] ou "Revogação da Lei de Imprensa". A Lei de Imprensa foi um grande instrumento de censura e a ADPF 130 tinha como objetivo a declaração de inconstitucionalidade de seus dispositivos. A liberdade de expressão, intrínseca ao trabalho da imprensa, sem dúvida estaria envolta nesta discussão.

Naquela oportunidade, o Ministro Joaquim Barbosa aduziu que a liberdade de imprensa, claramente pautada na liberdade de expressão "tem natureza e função multidimensionais. Ela deve ser também examinada sob a ótica dos destinatários da informação e não apenas à luz dos interesses dos produtores da informação" Contudo, os ministros advertiram que a defesa da liberdade de imprensa se confunde com a defesa de liberdade de expressão, e que como esta tem status de direito fundamental, não pode ser tolhida por uma Lei eivada de resquícios ditatoriais.

Mister transcrever as palavras do Ministro Menezes Direito, que reforça o estabelecimento de um sistema eficiente de freios e contrapesos, pois quanto mais forte se põe uma Instituição, mais frágil esta se torna em decorrência da arrogância: "nenhuma instituição pode arrogar-se em deter o absoluto, a vedação inconsequente de encontrar o seu espaço de agir desrespeitando o espaço de agir das outras instituições."

Na ocasião, o Supremo Tribunal Federal entendeu que a Lei de Imprensa não poderia permanecer no ordenamento jurídico brasileiro por ser totalmente incompatível com a Constituição Federal de 1988 e violar importantes preceitos fundamentais, como o da dignidade da pessoa humana e a liberdade de expressão, declarando como não recepcionada pela Constituição. 


\section{CONSIDERAÇÕES SOBRE O DIREITO DE IMAGEM}

Os direitos de personalidade como precedente ao direito de imagem. Pessoa, deriva do latim persona, vem de per (por) e sono (som) e se referia a máscara usada pelos atores nas representações teatrais em Roma e na Antiga Grécia.

Com o passar do tempo, persona passou a corresponder ao personagem que 0 ator representava, e mais adiante, a significar a própria pessoa como representante de papéis no cenário jurídico (DONNINI, 2002).

Esse ideal de pessoa que se fazia preponderante nos tempos primitivos têm importantes correlações com o que no século XXI se corresponde à pessoa humana, mas a tutela a seus direitos individuais não se fazia presente como na atualidade. Diogo Leite de Campos (1991. p. 321) ensina que "o ser se exprime (é) através de papéis funcionais em situações determinadas, ou por um lugar social que Ihe é atribuído por nascimento ou pelo funcionamento da sociedade". Da pessoa, advém a personalidade, que é o conjunto de caracteres exclusivos da pessoa, que agrupa os direitos e deveres que dela emana.

É o primeiro bem da pessoa, que lhe pertence como primeira utilidade, para que ela possa ser o que é, para sobreviver e se adaptar as condições do ambiente em que se encontra, servindo-lhe de critério para aferir, adquirir e ordenar outros bens (DINIZ, 2002. p. 453).

A tutela pelo ordenamento jurídico aos direitos de personalidade tem origem na Antiguidade, especificamente em Roma com a actio iniurarium e na Grécia, com a Hybris que desenvolvia um ideal de punir excessos, injustiça e desequilíbrios tentados contra a personalidade do ser humano (SZANIAWSKI, 2005), mas foi com a Declaração dos Direitos de 1789 e a Bills of Rights do estado da Vírginia, EUA, que a tutela dos direitos individuais do homem ganhou força (DINIZ, 2002). 
Os direitos da personalidade formam as disciplinas jurídicas que protegem os bens mais intrínsecos ao ser humano. Dentre eles estão à vida, integridade física, a privacidade, a imagem, entre outros.

Com efeito, nos tempos pretéritos não havia valorização alguma do indivíduo como sujeito, mas sim pelas condições que cercaram seu nascimento ou pelo trabalho por ele desenvolvido, o que na Roma era representado pelos três status: o libertatis, o civitatis e o familiae. Apesar da divergência doutrinária sobre o nascimento de tais direitos, entende-se que foi com o cristianismo e a igualdade de todos perante a Deus que surgiu a valorização do indivíduo, colocando o ser humano em situação de destaque absoluto (SOUZA, 1995).

Logo, a tutela dos direitos da personalidade sempre se fez presente na história da humanidade, mas a guinada do sujeito como centro do ordenamento jurídico só surgiu a partir do cristianismo.

É certo que em todos os tempos e em todas as fases da civilização romano-cristã, a proteção dos "direitos de personalidade" nunca em verdade faltou. Conceitos, normativos como teóricos, asseguraram sempre condições mínimas de respeito ao indivíduo, como ser, como pessoa, como integrante da sociedade. Todos os sistemas jurídicos, em maior ou menor escala, punem os atentados contra a vida, à integridade tanto física quanto moral. Isto não obstante, cabe assinalar que os "direitos de personalidade" incorporaram-se modernamente como estrutura organizacional, o que levou Milton Fernandes a dizer que a proteção jurídica aos direitos de personalidade é uma conquista de nosso tempo (PEREIRA, 2007. p. 308).

Com a promulgação da Constituição Federal de 1988, ficou definido como espécies do gênero direitos e garantias fundamentais, no Titulo II, dentre outros, os direitos individuais e coletivos (Capítulo 1, art. 5). Em função dos direitos de personalidade terem a possibilidade de ser individuais, sociais ou mesmo de solidariedade ou fraternidade, o direito a imagem, como direito de personalidade que é, ganhou status 
constitucional de Direito Fundamental. Até chegar no ápice do ordenamento jurídico brasileiro e ser objeto de inenarrável proteção, o direito de imagem seguiu longo e demorado processo.

A evolução da proteção dos direitos da intimidade em geral, como já explicitado, provém das sociedades mais antigas. Michele Keiko Mori (2001. p. 614) explica que "a noção de intimidade surgiu com o nascimento da burguesia como classe social". As pessoas tinham vontade e interesse de saber o que os mais ricos faziam, como se vestiam, com quem estavam casados ou se iam ter filhos. Segundo ela, "judicialmente, não há certeza quanto à primeira vez em que a proteção à vida privada foi acolhida. É comum se fazer referência a divulgação do retrato de uma famosa atriz em seu leito mortuário".

A primeira decisão jurisprudencial visando proteger o direito á imagem foi dada pelo Tribunal Francês em 16 de junho de 1858. A atriz francesa Rachel, quando faleceu, teve suas imagens no leito de morte reproduzidas sem a anuência de seus familiares. Revoltados, seus parentes pleitearam a destruição da imagem reproduzida junto ao Tribunal de Siene. "O fundamento residiu na impossibilidade de reprodução da imagem da pessoa no leito de morte, sem o consentimento da família, mesmo que se tratasse de uma celebridade, como Rachel" (TORRES, 1998. p. 134).

No nosso país, coube à modelo Zezé Leone, Miss Brasil 1922, protagonizar o primeiro caso envolvendo o direito à imagem. Ela teve sua imagem captada para a produção de um filme sem sua autorização e ingressou com ação judicial na $2^{\text {a }}$ Vara da Capital Federal. O Juiz competente, Excelentíssimo Sr. Octávio Kelly, compreendeu que era justa a pretensão contra um cinegrafista de filmes que fez imagem da modelo em ângulos inconvenientes.

Com o avanço da informática e a globalização, tornou-se praticamente impossível limitar e controlar o uso de imagens. No mundo digital, em apenas alguns cliques uma imagem pode estar em milhares de computadores, smartphones, tablets e televisores e isso repercute na vida do indivíduo em sociedade, já que a imagem, além de consistir 
naquilo que a pessoa ver e sabe de si mesma, também compreende a opinião pública, ou como as pessoas a enxergam diante no contexto social.

Questionamento importante sobre a tutela da imagem surgiu no corrente ano de 2015 quando o cantor sertanejo Cristiano Araújo sofreu um acidente de carro que culminou em sua morte. Poucos segundos após o óbito, fotos de seu cadáver já estavam entre as mais vistas de toda a internet. Os familiares de Cristiano, revoltados, deram entrevistas afirmando que iriam ingressar judicialmente em face dos sites que divulgaram as fotos e não tiveram respeito a imagem do falecido. Alegavam que o falecido tem direito a ter sua imagem preservada independente de estar vivo ou não. Ademais, merece respeito.

Antes da Constituição Federal de 1988, não havia no Brasil qualquer regramento que conferisse proteção jurídica a imagem do ser humano. A elevação desse direito de imagem ao nível de direito fundamental demonstra a importância notória e cristalina que o resguardo da imagem do indivíduo, ganhou com o passar dos anos e com o efeito massacrante da internet na sociedade civil. Para Carlos Bittar (2010), o direito a imagem consiste:

O direito que a pessoa tem sobre sua forma plástica e respectiva componentes distintas (rosto, olhos, perfil, busto) que a individualizam no seio da coletividade. Incide, pois, sobre a conformação física da pessoa, compreendendo esse direito um conjunto de caracteres que a identifica no meio social (BITTAR, 2010. p. 319).

Por outras palavras, é o vínculo que une a pessoa à sua expressão externa, tomada no conjunto, ou em partes significativas das pessoas.

Não obstante, a mais contundente forma para atingir os anseios do ser humano quanto a exposição de sua intimidade e dar plena efetividade ao princípio constitucional da dignidade da pessoa humana é dar proteção ao Direito á Imagem, como previsto no texto constitucional (art.5ํ, $\mathrm{V}$ e $\mathrm{X})$ : 
Art. 5: Todos são iguais perante a lei, sem distinção de qualquer natureza, garantindo-se aos brasileiros e aos estrangeiros residentes no País a inviolabilidade do direito à vida, à liberdade, à igualdade, à segurança e à propriedade, nos termos seguintes: (...)

V - é assegurado o direito de resposta, proporcional ao agravo, além da indenização por dano material, moral ou à imagem; (...)

$X$ - são invioláveis a intimidade, a vida privada, a honra e a imagem das pessoas, assegurado o direito a indenização pelo dano material ou moral decorrente de sua violação; (...).

Com uma vastíssima vitrine que vai muito além dos programas de auditório de antigamente, a pessoa pública de hoje tem uma abrangência muito maior do que a de 10 (dez) anos atrás, antes do "boom" da internet.

No início da década de 2000, quando os computadores ainda davam seus primeiros passos, as celebridades do país eram pessoas de notória especialização artística. Pessoas públicas eram os protagonistas de novelas, como Glória Pires e Tony Ramos, ou grandes damas do teatro como Fernanda Montenegro e Nathália Timberg. Também podiam ser jogadores de futebol como Pelé e Ronaldo Fenômeno, ou até apresentadoras famosas como Ana Maria Braga e Hebe Camargo.

Com a globalização e a interligação mundial por um clique, o conceito de pessoa pública sofreu grandiosa relativização. Hoje em dia, pessoa pública pode ser desde uma subcelebridade que namora um cantor famoso, um participante de um reality show, uma socialite que tem como hobby gastar dinheiro ou até a ex-amante de um político famoso. Ser chamado de pessoa pública deixou de ser um mérito daqueles que trabalharam e estudaram para desenvolver sua arte. É fácil ver as capas de revistas que antigamente eram estampadas por atrizes conceituadas, serem ocupadas por 'mulheres-frutas' que fazem de um muito para aparecer ou por exnamoradas de jogadores de futebol. A revista "Playboy", por exemplo, que já teve em suas capas atrizes de primeiro escalão como Vera Fischer e Maitê Proença, hoje têm 
mulheres que se tornaram famosas porque trocaram de roupa na área comum de um shopping.

Com a era digital, a Televisão, antigamente a quase única produtora das "pessoas públicas" começou a dividir espaço com a internet e por meio de aplicativos como Instagram, Snapchat e Periscope surgiram as webs celebrities. São pessoas que não tem programas de TV, não são atores, apresentadores ou humoristas. Suas atividades consistem em mostrar seu dia-a-dia, ou lifestyle como é chamado, para milhares de pessoas.

A blogueira Gabriela Pugliesi, por exemplo, expõe diariamente sua vida no aplicativo Snapchat, mostra seus treinos na academia, o que come, o que veste, o que gosta, o que não gosta, e acaba formando opinião e atraindo mídia e publicidade. Para que "Pugli" como é chamada na rede, poste alguma foto publicitária em seu Instagram, pode cobrar até $\mathrm{R} \$ 80.000,00$ (oitenta) mil reais. São os "digital influencers": pessoas que influenciam as outras pelo seu modo de vida.

Celebridades da TV também aderiram ao " hit" do novo milênio e diariamente negociam publicações em suas redes sociais repletas de seguidores. A atriz Bruna Marquezine que cresceu atuando em novelas da Globo, não posta nada em suas redes sociais sem uma prévia negociação com a marca em questão, e assim, acaba por expor sua vida intima e dando chance ao público que conheça quem está por trás dos personagens das telenovelas. O que ocorre é que esse público não se contenta em saber qual a marca preferida de biscoitos da atriz, mas também tem curiosidade em saber qual seu novo namorado, se já realizou intervenções cirúrgicas ou se brigou ou não com uma colega de elenco. A apresentadora Sabrina Sato, da TV Record, também não divulga marca alguma em seus perfis sociais sem um prévio contrato com a empresa. Essas publicidades variam do shampoo que "as famosas usam" até os carros "que os famosos usam".

Em 2014, quando lançou o "Up" a Wolkswagen do Brasil contratou a atriz Deborah Secco pra desfilar com um exemplar do carro pelas ruas do Rio de Janeiro. Bastaram algumas voltas da atriz para explodirem fotos suas em redes sociais e o crescimento 
de vendas entre mulheres de 22 a 30 anos aumentar. É literalmente a vida imitando a arte.

O moderno conceito de celebridade relembra à Europa do século XVIII, onde o rei era a grande estrela e quem estava a seu redor, também ganhava status de pessoa pública. É muito comum que esposas, maridos, namoradas e amantes fiquem conhecidas única e exclusivamente por se relacionarem com pessoas públicas. Exemplo elucidativo é o do cantor Zezé di Camargo, que viu sua ex-mulher, Zilú, se tornar apresentadora de TV após a fama que ganhou com os boatos que rodearam sua separação. A nova companheira de Zezé também já colhe os louros da fama, se tornou uma digital influencer e tem centenas de seguidores nas suas redes sociais, onde divulga diariamente inúmeras marcas que "adora".

O Tribunal de Justiça do Estado do Rio de Janeiro, local onde há grande concentração de pessoas públicas, já se pronunciou distinguindo celebridades instantâneas e pessoas famosas de fato: "artistas de renome não se consideram as celebridades, aquelas que vem, e cedo se vão, dependendo de sua empresa de marketing. Artistas são aqueles que, ao longo dos anos se mantêm em evidência pelo seu trabalho".[6]

Ante essa exposição imoderada e generalizada, a proteção do direito a imagem passa a ser discutida sob um prisma de necessidade. É questionável se seria necessário tutelar a imagem de pessoas que se expõem tanto e de forma "gratuita". Porém, são essas pessoas que mais buscam a tutela do Estado para ver resguardado seu direito a imagem.

É inegável que os artistas têm na imagem sua fonte de renda, mas a exposição voluntária e desarrazoada suscita a questão sobre até que ponto tais pessoas podem requerer a tutela de seus direitos, quando na verdade violam a si próprios dando liberdade de terem suas vidas invadidas.

A imagem então, adquire status máximo num século marcado pelo culto ao corpo, ao cabelo, as celebridades e a mídia. A socialite Kim Kardashian a título de exemplificação, é uma das famosas mais bem pagas do mundo, e não exerce 
nenhuma profissão. Ganhou fama e prestígio após emplacar um reality no canal E! Television (Keeping Up With The Kardashians) mostrando o dia a dia de sua família e do seu casamento com o rapper Kanye West. Não é atriz, modelo, dançarina ou apresentadora. Apenas uma mulher americana que tem problemas familiares e conflitos com amigas. Não obstante, a imagem ter tido uma elevada importância no início da década de 2000, atingindo um número ilimitado de receptores, o progresso dos meios de comunicação e da fixação da imagem da celebridade acabou tornandoa uma espécie de semi-Deus no imaginário do público. Pessoas que aparentemente tem a vida perfeita, o carro perfeito, o casamento perfeito, a roupa perfeita.

Logo, o resultado é um direito a imagem como prerrogativa da pessoa pública. Pessoa pública essa que pode concordar ou discordar que elementos nucleares de sua imagem moral ou física sejam utilizados como objeto de lucro e que como qualquer outra, faz jus a proteção estatal como garantidor de um direito fundamental.

\section{ESTUDO DE CASOS ENVOLVENDO CONFLITOS NORMATIVOS DE PROTEÇÃO À IMAGEM versus LIBERDADE DE IMPRENSA}

A materialização do direito à imagem acontece todos os dias. É comum notícias de artistas que ingressam em juízo contra jornais, revistas, e publicações que divulgam informações de sua vida íntima. Além da proteção ao próprio artista, algumas vezes o direito à imagem também abarca direitos do de cujus, do nascituro e da imagem usada com excesso pelo veículo de comunicação. É a relativização do direito imagem para proteger o foro íntimo dos artistas.

\subsection{DA POSSIBILIDADE DE PROTEÇÃO AO NASCITURO (CASO RAFINHA BASTOS versus WANESSA CAMARGO)}

Demonstração da ampla abrangência e do sentido lato sensu dos direitos relativos à imagem é aquele direito que tange ao nascituro, entendido este como sujeito de direito que não dispõe de personalidade jurídica. Miguel Reale (2003. p. 194), em acertada lição, diz que "aos incapazes e mesmo aos nascituros correspondem direitos, sem 
que, evidentemente, possam ser considerados 'expressão de sua vontade', tanto assim que são exercidos por seus representantes, quando não por órgãos do Estado".

Posição semelhante é adotada por Marcus Cláudio Acquaviva (2000. p. 265) ao verficar que "o produto da concepção (feto ou embrião) ainda não é pessoa, mas tem a consideração da lei para determinados efeitos. Não é sem razão que a lei civil põe a salvo os direitos do nascituro desde a concepção".

O caso de maior repercussão envolvendo o direito de imagem do nascituro é sem dúvida o que envolve a cantora Wanessa Camargo e o apresentador Rafinha Bastos, por serem pessoas públicas.[7]

Wanessa estava grávida de seu primeiro filho, fruto da relação com o empresário paulista Marcos Buaiz quando Rafinha, durante o programa no qual era apresentador, da Rede Bandeirantes de Televisão: "CQC - CUSTE O QUE CUSTAR" afirmou que teria relações sexuais com a mãe e com o bebê, em estranho elogio a beleza que a cantora ostentava na gravidez.

O comentário gerou repercussão inimaginável nas redes sociais, bem como fúria por parte do casal Wanessa e Marcos que, totalmente impressionados com a falta de respeito à mãe e filho, ajuizaram ação de indenização por danos morais em face do apresentador e prestaram queixa-crime contra o mesmo.

A classe artística se voltou contra Rafinha que inclusive, foi demitido da TV Bandeirantes por imposição de Buaiz, empresário de prestígio do meio artístico. O humorista também perdeu inúmeros contratos publicitários e foi entregue ao escárnio da opinião pública.

Na petição inicial, o casal Wanessa e Marcos, acompanhados do nascituro, alegam que Rafinha não se retratou do comentário tecido, mesmo após ter sido afastado do programa. Também zombou da situação ao postar em seu perfil nas redes sociais imagens de mulheres grávidas seminuas e vídeos seus em churrascarias, dispensando ofertas de "baby beef". "fraldinha" e "coisas para bebê (bebida)". 
O Réu alegou ilegitimidade ativa do nascituro, logo afastada pelo magistrado, que deu procedência ao pedido e condenou o artista ao pagamento de indenização por dano moral em dez salários mínimos para cada um dos autores.

Sem esquecer da liberdade de imprensa para alcançar o progresso numa nação livre, o juiz Luiz Beethoven Giffoni Ferreira alegou a liberdade de imprensa precisa respeitar os direitos e garantias fundamentais de qualquer cidadão, o que não aconteceu no caso em questão. Suscitou a linguagem vulgar proferida pelo apresentador, que ofendeu a moral da família e atingiu, inclusive, o nascituro.

Quanto à discussão acerca da legitimidade do nascituro em figurar no polo ativo da demanda, o Juiz entendeu que era perfeitamente possível tendo em vista que a esfera moral do nascituro pode evidentemente sofrer vulneração "pelo simples fato de que já é pessoa para os fins preconizados na Lei". Cita, em sua decisão, Carvalho Santos para concluir que o nascituro é tido como já existido de acordo com a doutrina do Código Civil, todas as vezes que o caso se tratar de amparar seus interesses.

Interpostas apelações por ambas as partes, o réu objetivou a extinção do processo em decorrência da ilegitimidade ativa do nascituro, tendo os autores, por meio de recurso adesivo, pleiteado a majoração do quantum indenizatório.

Apesar das alegações da defesa de abuso ao direito de expressão por parte do artista, já que a afirmação seria uma piada e não uma agressão, a Quarta Turma do Superior Tribunal de Justiça (STJ) resolveu manter a decisão da Justiça de São Paulo que condenou o humorista a indenizar a cantora em $R \$ 150.000,00$. No entendimento do ministro Marco Buzzi, relator do caso, o comentário de Rafinha Bastos foi violento e extrapolou o direito de expressão ao ofender a dignidade da cantora. O magistrado ressaltou ainda que o insulto de Rafinha atingiu também o filho de Wanessa, nascituro à época do fato.

Para ele, a declaração ultrapassou o limite do mero aborrecimento tendo causado efetivo dano moral, já que foi muito além do propósito jocoso e irônico que se admitiria na fala de um humorista. Segundo o entendimento dos ministros, o comentário do 
apresentador dá conta de que ele gostaria de manter relações sexuais com a cantora e seu filho que sequer havia nascido, efetivando assim, o abalo moral.

No processo criminal, a Justiça decidiu que o humorista não cometeu injúria contra o nascituro. A juíza Juliana Gueif, da $14^{\mathrm{a}}$ Vara Criminal de São Paulo alega que o filho da cantora Wanessa, não tinha, na época do fato, consciência da ofensa que ocorreu e por isso o crime não pode ser caracterizado.

A cantora ingressou com recurso alegando que seu filho poderia ter sofrido com o reflexo da angústia vivida pela mãe, enquanto se desenvolvia, porém os desembargadores da $13^{\mathrm{a}}$ Câmara de Direito, mantiveram, de forma unânime a decisão tomada em novembro de 2011 pelo juízo de $1^{\circ}$ grau.

A decisão de negar se baseou pelo fato de os desembargadores entenderam que a ofensa não foi suficiente para caracterização de injúria contra o bebê, já que se tratava de algo que exigia que a vítima tivesse consciência da sua dignidade ou decoro. "Daí o acerto da decisão recorrida ao proclamar 'inevitável se reconhecer que o nascituro não pode ser sujeito passivo de injúria" disse França Carvalho, desembargador e relator do caso, complementando que "no caso, não tem a mínima capacidade psicológica de entender os termos e o grau da ofensa à sua dignidade e decoro".

\subsection{CASO CAROLINA DIECKMANN E SUAS REPERCUSSÕES}

Outra pessoa pública que teve seus direitos relativos à imagem violados foi a atriz brasileira Carolina Dieckmann. A artista protagonizou, talvez, o mais famoso caso de direitos relativos à imagem, tendo seu nome hoje usado para identificar a Lei $n^{\circ}$ 12.737[8], que dispõe sobre a tipificação criminal de delitos informáticos.

No dia 7 de maio de 2012, após tentativa de extorsão, Dieckmann teve 36 (trinta e seis) fotos pessoais divulgadas na internet, recebendo ameaças de extorsão desde o final do mês de março daquele ano. Os criminosos requereram a quantia de $\mathrm{R} \$ 10.000,00$ (dez mil reais) para não efetivarem a publicação das fotos da artista. 
Segundo o delegado responsável pelo caso, Dr. Rodrigo de Souza Valle, a subtração das fotos teria começado com um e-mail usado como isca (spam) que, ao ser aberto, liberou uma porta para instalação de um programa que permitiu aos hackers entrarem no computador da atriz.

A publicação de imagens de fotos chocantes, brutais, nuas, ou mostrando nudez, dá ensejo a indenização por danos morais. No caso das fotos da atriz, não se trata de liberdade de expressão por parte dos hackers, e sim de caso típico de invasão de privacidade e violação a direito de imagem da atriz da Rede Globo.

A lei estabelece requisitos para configurar violação, bem quando é legítima a divulgação de imagem. Assim, é legalizado pelo do disposto no art. 20 do Código Civil[9], quando dispõe que:

Salvo se autorizadas, ou se necessárias à administração da justiça ou à manutenção da ordem pública, a divulgação de escritos, a transmissão da palavra, ou a publicação, a exposição ou a utilização da imagem de uma pessoa poderão ser proibidas, a seu requerimento e sem prejuízo da indenização que couber, se the atingirem a honra, a boa fama ou a respeitabilidade, ou se se destinarem a fins comerciais.

Sem autorização, não se pode livremente divulgar a imagem de uma pessoa alegando "liberdade de expressão", e mesmo com a autorização, qualquer atitude que venha a extrapolar os limites da mesma para a exposição das imagens será tido como ilícito e, por isso mesmo, a autorização para exposição de imagens e uma cediço de determinada revista não pode ser estendida ao uso das mesmas imagens em outras publicações. A publicação da imagem de uma pessoa, sem a sua autorização, para fins econômicos ou comerciais gera direito à indenização. No ano de 2000, a $3^{2}$ Turma garantiu à atriz Maitê Proença o direito a receber indenização por dano moral da Tribuna da Imprensa em virtude da publicação não autorizada de uma foto extraída de ensaio fotográfico feito para a revista "Playboy", em julho de 1996. As fotos foram publicadas no mês seguinte na edição comemorativa do $21^{\circ}$ aniversário da mesma revista.[10] 
Naquela situação, para aceitar o trabalho, a atriz transacionou, em contrato escrito, os requisitos para cessão de sua imagem, designando a remuneração e o tipo de fotos que seriam produzidas, em clara preocupação com a sua imagem e a qualidade do trabalho, de modo a restringir e controlar a forma de divulgação de sua nudez nas páginas da publicação. Porém, em 10 de agosto o jornal estampou uma das fotos, extraída do ensaio para a "Playboy", em página inteira, sem qualquer autorização da artista.

Para a Turma, a atriz sofreu violência em seu crédito como pessoa, pois deu o seu direito de imagem a uma revista que abrange determinado grupo da população e poderia não querer que outro grupo da população tivesse acesso a essa imagem. Os Ministros afirmaram que ela é uma pessoa pública, mas nem por isso tem que aceitar que sua imagem seja publicada em lugar que jamais autorizou, tendo experimentado, naquela ocasião, sentimentos de raiva, dor, desilusão, por ter visto sua foto em publicação que não foi de sua vontade. Por essa razão, faria jus a indenização.

Já em 2008, em julgamento do REsp 1.082.878[11], a 3ª Turma manteve decisão que obrigou a Editora Globo, que faz parte do mesmo grupo econômico da Rede Globo, empregadora do ator Marcos Pasquim, a pagar indenização no valor de $\mathrm{R} \$ 5.000,00$ (cinco mil reais) ao mesmo, por danos morais decorrentes da publicação de uma foto dele beijando uma mulher desconhecida, fato que teria provocado consequências para sua família e ofendido seu matrimônio.

Para a relatora, Ministra Nancy Andrighi:

A doutrina e a jurisprudência são pacíficas no sentido de entender que pessoas públicas ou notórias têm seu direito de imagem mais restrito que pessoas que não ostentem tal característica. Em alguns casos, essa exposição exagerada chega a Ihes beneficiar. Entretanto, nesse caso ficou caracterizado o abuso no uso da reportagem. 


\subsection{CASO CÁSSIA KIS}

Uma das atrizes mais respeitadas do Brasil também foi autora de um dos poucos processos sobre direito à imagem enfrentado pela mais alta Corte do Brasil. Cassia Kiss teve uma foto sua publicada, sem autorização, na capa de duas revistas: "Remédios Caseiros" e "Coquetel". As fotos não tinham conteúdo constrangedor, mas a atriz sentiu violado seu direito à imagem e ingressou com ação de indenização, pleiteando a reparação dos danos materiais e morais.

Por meio do RE 215.984-1 RJ[12] a atriz alegou que inexistia fato incontroverso já que o uso não autorizado de suas fotografias na publicação era comprovado de plano. Suscitou que havia divergência entre o acórdão recorrido e a jurisprudência do Supremo Tribunal Federal (RE 95.872-RJ, $1^{\text {a }}$ turma, Rafael Meyer, RTJ 104/801)[13] e do Superior Tribunal de Justiça (Súmula 37/STJ).

O ministro relator Carlos Velloso destacou que a Constituição Federal assegura no art. 5, inciso X[14], a inviolabilidade da imagem das pessoas e a indenização pelos danos materiais e morais decorrentes de sua violação. Disse também que a imagem da atriz é um direito que the pertence e foi obtido ao longo de sua carreira, compondo seu patrimônio econômico e não pode ser utilizado sem a sua permissão, principalmente em revistas com cunho publicitário.

Em acertada lição, o eminente Ministro Rafael Meyer ao relatar o RE 95.872, mesmo antes da Nova Constituição, já afirmava: "o dever de indenizar decorre da simples utilização de um direito personalíssimo, o da imagem".

No que se refere à publicação de fotografias, sem o consentimento do fotografado, doutrina e jurisprudência brasileira são no sentido da ocorrência de dano moral que deve ser reparado. Yussef Said Cahali aduz que:

Em linha de princípio, a utilização de imagem constitui direito exclusivo e personalíssimo, inerente à reserva de governo sobre a própria pessoa, quer para dispor, como para impedir a liberação a terceiros, mediante 
paga ou não; a violação desse direito dá ensejo à correspondente indenização, seja perpetrada com intuito de propaganda lucrativa, seja para difamar.

E acrescenta: "sob tal aspecto, é válido dizer-se, com Demongue, que 'le fait d'exposer le portrait d'une personne contre as volonté peut donner lieu à indemnité[15]'”. O STF concordou com a atriz e reconheceu tanto o dano material quanto o dano moral, gerando a seguinte decisão:

Dano moral - Ação indenizatória - Direito à imagem - Publicação de fotografia sem autorização - Estado de desconforto, aborrecimento ou constrangimento que, independentemente do seu tamanho e do intuito comercial, é causado pela publicação da fotografia de alguém Desnecessidade de ofensa para que exista reparação de dano Inteligência do art. $5^{\circ}, \mathrm{X}$, da CF.

Para a reparação do dano moral não se exige a ocorrência de ofensa à reputação do indivíduo. O que acontece é que, de regra, a publicação da fotografia de alguém, com intuito comercial ou não, causa desconforto, aborrecimento ou constrangimento, não importando o tamanho desse desconforto, desse aborrecimento ou desse constrangimento. Desde que ele exista, há o dano moral, que deve ser reparado, manda a Constituição, art. 5, X.DANO MORAL. Cobrança cumulada com danos materiais. Admissibilidade. Publicação não autorizada de fotografia. Violação do direito à imagem. Dever de reparar danos materiais e compensar os morais, independentemente de ter sido afetada ou não a reputação da vítima.É possível a cumulatividade da cobrança do dano material aos danos morais, na hipótese de publicação não autorizada de fotografia, uma vez que presente o dever de reparar os danos materiais e compensar os morais, já que violado o direito de imagem, independentemente de ser afetada ou não a reputação da vítima. (STF - 2를 T.; RE no 215.984-1-RJ; Rel. Min. Carlos Velloso; j. 4/6/2002; v.u.) RT 802/145. 
Assim, por todos os casos concretos expostos no presente estudo, verifica-se que nossas Cortes têm entendido no sentido de buscar a proteção de bem imaterial, a imagem, onde, em casos concretos nos quais se acham em conflito os direitos da liberdade de expressão e o direito à proteção da imagem, relativizam o primeiro em clara predileção ao resguardo do bem juridicamente protegido.

\section{CONCLUSÃO}

A internet proporcionou novas opções de comunicação e interação, tendo um caráter legitimamente descentralizador no que tange ao acesso a informação, possibilitando a qualquer tempo, a livre expressão do cidadão.

Pelo seu viés democrático, essa rede acaba possibilitando que tal liberdade tão bem assegurada pela Constituição Federal de 1988, possa ser executada de forma material, culminando na distribuição de ideais, pensamentos e opiniões sobre temas não tão relevantes, e quase sempre, profundamente particulares, principalmente quando correlacionados

a pessoas públicas.

Em decorrência da análise realizada no presente artigo, fica claro que quando conflitantes, a liberdade de expressão e o direito a imagem se tornam um verdadeiro obstáculo na seara Jurisprudencial.

De um lado artistas que se expõe de forma imoderada, colocando sua alimentação, seu vestuário, seus carros e seus planos em redes sociais, e muitas vezes dividindo até seus medos e expectativas com pessoas que sequer conhecem.

Esses mesmos artistas buscam ter sua imagem protegida, apesar de, em inúmeros casos, seus atos serem o fio condutor para a insaciável vontade do público pela informação fútil. Em essência, pleiteiam o direito a imagem que lhes é assegurado pelo Diploma Constitucional, mas precisam se expor para manter o lucro obtido por publicações diárias em aplicativos digitais, aparições em programas de TV e contratos publicitários. Quando decidem se expor, esses artistas por muitas vezes, acabam prejudicando outros colegas de classe, que com a vida bem menos exposta, tem que 
suportar o ônus de ser "celebridade" e não puramente "artista" num país com imprensa preponderantemente voltada ao jornalismo de celebridades. Não é raro que em grandes portais da internet como o R7, do Grupo Record de Comunicação, o blog mais acessado não seja o de economia ou de política, e sim o que trata da vida íntima das celebridades - como é o caso do da blogueira paulista Fabiola Reipert.

De outro lado, uma imprensa feroz e ativista, que tem como público-alvo aqueles que dão o sustento dos reivindicadores do direito à imagem: o povo. Do mesmo modo que compra, segue e divulga seus artistas favoritos, o povo, de forma paradoxal funciona como principal patrocinador da imprensa invasiva. É o público que quer ver sua atriz favorita indo a padaria, que quer saber quem é o novo namorado de uma cantora famosa, que quer saber se uma atriz de idade avançada está se relacionando com um rapaz mais jovem, ou até se uma protagonista de novelas do horário nobre é ou não homossexual.

Recai sobre o Poder Judiciário resolver esse conflito, sempre buscando os princípios da razoabilidade e proporcionalidade. Ao mesmo tempo que é visto como inadmissível que um fotógrafo sobrevoe com helicóptero a casa de um famoso só para saber se ele está ou não namorando alguma pessoa, é digno de questionamento a admissibilidade do mesmo famoso combinar com o fotógrafo um "flagra" em determinada praia carioca.

Ante aos tópicos suscitados no presente artigo, desde a evolução histórica do direito de Imprensa, percorrendo a efetivação da liberdade de expressão e a importância constitucional do Direito de imagem, não obstante a exposição de entendimentos da Jurisprudência dominante em casos envolvendo o conflito de tais direitos, conclui-se que num conflito entre estes direitos fundamentais, deve prevalecer aquele que tutela o Direito à imagem.

Apesar da exposição desmedida das pessoas públicas, todo e qualquer indivíduo deve ter direito a sua intimidade e de controlar a maneira de exposição de sua imagem perante a coletividade. Não é porquê uma atriz posa nua para o exemplar mensal de uma revista de conteúdo adulto que ela dá direito a ser fotografada nua 
todos os outros dias de vida, bem como a que a revista publique fotos de seu ensaio nu em todos os meses seguintes, independente de expressa previsão contratual.

O direito a imagem é um direito de personalidade, e como tal, corresponde ao que há de mais intimo do indivíduo. Apesar da liberdade de expressão ser Direito Fundamental e ter status máximo na Constituição Federal, não pode ser preterido diante da proteção daquilo que há de mais privado ao ser humano, ainda mais, sendo esse o centro do ordenamento jurídico.

\section{REFERÊNCIAS}

ACQUAVIVA, Marcus Cláudio. Dicionário Jurídico Brasileiro Acquaviva. 11. ed. São Paulo: Jurídica Brasileira, 2000.

AQUINO, Maria Aparecida de. Censura, Imprensa e Estado autoritário (19681978): o exercício cotidiano da dominação e da resistência: O Estado de São Paulo e Movimento. Bauru: EDUSC, 1999.

BITTAR, Carlos Alberto. Os Direitos da Personalidade. 1995. São Paulo; LTr, 2010.

BONAVIDES, Paulo. Curso de Direito Constitucional. 9. ed. São Paulo: Malheiros, 2000.

BRASIL. Apelação Cível no 0119701-79.2002.8.19.0001. Tribunal de Justiça do Rio de Janeiro. Relator Desembargador Ademir Paulo Pimentel. Disponível em: $<$ http://www.tjij.jus.br/scripts/weblink.mgw?

MGWLPN $=J U R I S \& L A B=C O N \times W E B \& P O R T A L=1 \& P O R T A L=1 \& P G M=W E B P C N U 88$ $\& N=200300135646 \&$ Consulta $=\& C N J=0119701-79.2002 .8 .19 .0001>$. Acesso em: 27 set. 2015.

BRASIL. Ato Institucional no 5 de 13 de dezembro de 1968. São mantidas a Constituição de 24 de janeiro de 1967 e as Constituições Estaduais; O Presidente da República poderá decretar a intervenção nos estados e 
municípios, sem as limitações previstas na Constituição, suspender os direitos políticos de quaisquer cidadãos pelo prazo de 10 anos e cassar mandatos eletivos federais, estaduais e municipais, e dá outras providências. Diário Oficial da União. Brasília, 13 out. 1968. Disponível em: <http://www.planalto.gov.br/ccivil_03/AIT/ait-05-68.htm>. Acesso em: 25 out. 2015.

BRASIL. Constituição (1988). Constituição da Republica Federativa do Brasil. Brasília: Senado Federal, $1988 . \quad$ Disponível em: <http://www.planalto.gov.br/ccivil_03/Constituicao/Constituicao.htm>. Acesso em: 02 out. 2015.

BRASIL. Lei oㅜ 5.250 de 9 de fevereiro de 1967. Regula a liberdade de manifestação do pensamento e de informação. Diário Oficial da União. Brasília, 9 fev. 1967. Disponível em: <http://www.planalto.gov.br/ccivil_03/leis/L5250.htm>. Acesso em: 07 out. 2015.

BRASIL. Lei ํㅜ 10.406 de 10 de janeiro de 2002. Institui o Código Civil Brasileiro. Diário Oficial da União. Brasília, 10 jan. 2002. Disponível em: <http://www.planalto.gov.br/ccivil_03/leis/2002/L10406.htm>. Acesso em: 05 out. 2015.

BRASIL. Lei № 12.737 de 30 de novembro de 2012. Dispõe sobre a tipificação criminal de delitos informáticos; altera o Decreto-Lei $n^{\circ} 2.848$, de 7 de dezembro de 1940 - Código Penal; e dá outras providências. Diário Oficial da União. Brasília, 30 nov. 2012. Disponível em: <http://www.planalto.gov.br/ccivil_03/_ato2011 2014/2012/lei/l12737.htm>. Acesso em: 05 out. 2015.

BRASIL. Superior Tribunal de Justiça. Ementa: CIVIL E PROCESSUAL. AÇAO DE INDENIZAÇAO POR USO INDEVIDO DE IMAGEM. PUBLICAÇAO NAO $\begin{array}{llll}\text { AUTORIZADA DE } & \text { FOTO INTEGRANTE } & \text { DE } & \text { ENSAIO }\end{array}$ FOTOGRÁFICO CONTRATADO COM REVISTA ESPECIALIZADA. DANO MORAL. FIXAÇAO EM PATAMAR EXCESSIVO. REDUÇAO. POSSIBILIDADE, INCASU. (REsp 764735 RS 2005/0110506-4. Rel. Ministro Honildo Amaral de Mello Castro. 
Quarta Turma. Data do Julgamento 05/11/2009. Data da Publicação). Diário da Justiça. Brasília, 05 nov. 2009. Disponível em: <http://stj.jusbrasil.com.br/jurisprudencia/8584070/recurso-especial-resp-764735-rs2005-0110506-4/inteiro-teor-13671997>. Acesso em: 01 out. 2015.

BRASIL. Supremo Tribunal Federal. Arguição de Descumprimento de Preceito Fundamental 130. Diário da Justiça. Brasília, 30 abr. 2009. Disponível em: $<$ http://redir.stf.jus.br/paginadorpub/paginador.jsp?docTP=AC\&docID=605411>. Acesso em: 12 out. 2015.

BRASIL. Supremo Tribunal Federal. Ementa: CONSTITUCIONAL. DANO MORAL: FOTOGRAFIA: PUBLICAÇÃO NÃO CONSENTIDA: INDENIZAÇÃO: CUMULAÇÃO COM O DANO MATERIAL: POSSIBILIDADE. Constituição Federal, art. 5ㅇ, X. (RE 215984 RJ. Rel. Carlos Velloso. Segunda Turma. Data do Julgamento 04/06/2002. Data de Publicação). Diário da Justiça. Brasília, 04 jun. 2002. Disponível em: <http://stf.jusbrasil.com.br/jurisprudencia/774207/recurso-extraordinario-re-215984rj<. Acesso em: 01 out. 2015.

CAMPOS, Diogo Leite de. Lições de direitos da personalidade. Boletim da Faculdade de Direito da Universidade de Coimbra. Coimbra: Universidade de Coimbra, 1991, v. LXVII.

CANOTILHO, J. J. Gomes; MACHADO, Jónatas E. M. "Reality shows" e Liberdade de Programação. Coimbra: Coimbra, 2003.

COSTA, Bruno. Al-5: O golpe dentro do golpe. In: Quotidiano. São José da Barra. 13 dez. 2013. Disponível em: <http://www.quotidiano.com.br/impressao-395/ai-5:-ogolpe-dentro-do-golpe>. Acesso em: 27 out. 2015.

CRUZ, Marco Aurélio Rodrigues da Cunha e. A evolução conceitual da liberdade de expressão na jurisprudência do Supremo Tribunal Federal. Joaçaba: Espaço Jurídico, 2010.

Disponível em: <http://editora.unoesc.edu.br/index.php/espacojuridico/article/viewFile/1955/1023>. Acesso em: 12 out. 2015. 
DENARDI, Eveline Gonçalves. A liberdade de expressão a partir da Constituição de 1988. 2011. Disponível em: <http://www.webartigos.com/artigos/a-liberdade-deexpressao-a-partir-da-constituicao-de-1988/62562/>. Acesso em: 29 out. 2015.

DINIZ, Maria Helena. Curso de direito civil brasileiro. 18. ed, São Paulo: Saraiva, 2002, v. 1.

DONNINI, Oduvaldo; DONNINI, Rogério Ferraz. Imprensa livre, dano moral, dano à imagem e sua qualificação á luz do novo Código Civil. São Paulo: Método, 2002.

ELIAS, Beatriz. O Al-5, a censura à imprensa e a reação de 0 Diário. In: A Província. Piracicaba, 29 dez. 2013.

FERRARI, Pollyana. Jornalismo digital. São Paulo: Contexto, 2003.

FERREIRA FILHO, Manoel Gonçalves. A democracia possível. 5. ed. São Paulo: Saraiva, 1979.

. Comentários à Constituição brasileira. 5.ed. São Paulo: Saraiva, 1984.

LIMA, Venicio Artur de. Liberdade de expressão X Liberdade de imprensa. 2. ed. São Paulo: Publisher, 2012.

LOUREIRO, Henrique Vergueiro. Direito à imagem. São Paulo: Pontifícia Universidade Católica, 2005. Disponível em: < http://www.sapientia.pucsp.br/tde_arquivos/9/TDE-2005-09-20T11:48:05Z1308/Publico/HenriqueLoureiro.pdf>. Acesso em: 18 out. 2015.

MELO, Patrícia Bandeira de. Um passeio pela história da imprensa: o espaço público dos grunhidos ao ciberespaço. In: Comunicação \& Informação. Goiás, 2005. Disponível em: $<$ http://www.revistas.ufg.br/index.php/ci/article/viewFile/24592/14116>. Acesso em: 09 out. 2015. 
MORAES, Alexandre de. Constituição do Brasil interpretada e legislação constitucional. São Paulo: Atlas, 2002.

MORI, Michele Keiko. Direito à Intimidade versus Informática. 1. ed. Curitiba: Juruá, 2001.

PEREIRA, Caio Mário da Silva. Instituições de Direito Civil. Rio de Janeiro: Forense, 2007.

REALE, Miguel. Lições Preliminares de Direito. 27. ed. São Paulo: Saraiva, 2003.

SÃO PAULO. Tribunal de Justiça. Ementa: USO INDEVIDO DE IMAGEM INDENIZAÇÃO POR DANOS MATERIAIS E MORAIS Julgamento antecipado Cerceamento de defesa Não configurado - Indenização devida pela veiculação da imagem da autora sem a necessária autorização Afronta ao disposto no artigo 24 da Lei 9.610/98 - Desnecessidade de demonstração do prejuízo, pois o dano está representado pela própria utilização indevida, que visa obter com isso vantagem Montante fixado a título de indenização $(R \$ 15.000,00)$ que não se mostra apto a reparar os danos causados Arbitramento em $\mathrm{R} \$ 30.000,00$ que se aproxima de 50 salários mínimos que se mostra razoável e em consonância com diversos precedentes desta Turma Julgadora - Sentença reformada apenas no tocante ao quantum indenizatório Recurso da autora parcialmente provido e improvido o recurso da ré. (RTJ 104/801. Rel. Salles Rossi. Data do Julgamento 16/01/2013. Data de Publicação). Diário da Justiça. São Paulo, 16 jan. 2013. Disponível em: <http://tjsp.jusbrasil.com.br/jurisprudencia/23019155/apelacao-apl-16190720118260510-sp0001619-0720118260510-tjsp/inteiro-teor-111201965>. Acesso em: 30 set. 2015.

SODRÉ, Nelson Werneck. História da Imprensa no Brasil. São Paulo: Mauad, 1994.

SOUSA, Jorge Pedro. Elementos de Teoria e Pesquisa da Comunicação e dos Media. Porto: Universidade Fernando Pessoa, 2003. Disponível em: < http://bocc.unisinos.br/pag/sousa-jorge-pedro-elementos-teoria-pequisacomunicacao-media.pdf>. Acesso em: 13 out. 2015. 
SOUZA, Rabindranath Valentino Aleixo Capelo de. O direito geral de personalidade. Coimbra: Coimbra, 1995.

SZANIAWSKI, Elimar. Direitos de personalidade e sua tutela. São Paulo: Revista dos Tribunais, 2005.

TORRES, Patrícia de Almeida. Direito à Própria Imagem. São Paulo: LTR, 1998.

VALENTINO, Ângela Maria. A evolução dos direitos fundamentais e as transformações do sistema constitucional. In: Âmbito Jurídico. Rio Grande, XV, n. 105, 2012. Disponível em: <http://www.ambitojuridico.com.br/site/index.php/?n_link=revista_artigos_leitura\&artigo_id=12319\&revist a_caderno=9>. Acesso em: 27 nov. 2015.

\section{APÊNDICE - REFERÊNCIAS DE NOTA DE RODAPÉ}

2. Ementa: Arguição de descumprimento de preceito fundamental (ADPF). Lei de imprensa. Adequação da ação. Regime constitucional da "liberdade de informação jornalística", expressão sinônima de liberdade de imprensa. A "plena" liberdade de imprensa como categoria jurídica proibitiva de qualquer tipo de censura prévia. A plenitude da liberdade de imprensa como reforço ou sobretutela das liberdades de manifestação do pensamento, de informação e de expressão artística, científica, intelectual e comunicacional. Liberdades que dão conteúdo às relações de imprensa e que se põem como superiores bens de personalidade e mais direta emanação do princípio da dignidade da pessoa humana. O capítulo constitucional da comunicação social como segmento prolongador das liberdades de manifestação do pensamento, de informação e de expressão artística, cientifica, intelectual e comunicacional. Transpasse da fundamentalidade dos direitos prolongados ao capítulo prolongador. Ponderação diretamente constitucional entre blocos de bens de personalidade: o bloco dos direitos que dão conteúdo à liberdade de imprensa e o bloco dos direitos à imagem, honra, intimidade e vida privada. Precedência do primeiro bloco. Incidência a posteriori do segundo bloco de direitos, para o efeito de assegurar o direito de resposta e assentar responsabilidades penal, civil e administrativa, entre outras 
consequências do pleno gozo da liberdade de imprensa, peculiar fórmula constitucional de proteção a interesses privados que, mesmo incidindo a posteriori, atua sobre as causas para inibir abusos por parte da imprensa. Proporcionalidade entre liberdade de imprensa e responsabilidade civil por danos morais e materiais a terceiros. Relação de mútua causalidade entre liberdade de imprensa e democracia. Relação de inerência entre pensamento crítico e imprensa livre. A imprensa como instância natural de formação da opinião pública e como alternativa à versão oficial dos fatos. Proibição de monopolizar ou oligopolizar órgãos de imprensa como novo e autônomo fator de inibição de abusos. Núcleo da liberdade de imprensa e matérias apenas perifericamente de imprensa. Autorregulação e regulação social da atividade de imprensa. Não recepção em bloco da lei № 5.250/1967 pela nova Ordem Constitucional. Efeitos jurídicos da decisão. Procedência da ação.

3.

Disponível

em:

$<$

http://www.senado.gov.br/senado/grandesMomentos/marcio_alves.shtm>.

Acesso em: 25 out. 2015.

4. Disponível em: <http://www.planalto.gov.br/ccivil_03/AlT/ait-05-68.htm>. Acesso em: 25 out. 2015.

5.

Disponível

em:

$<$ http://redir.stf.jus.br/paginadorpub/paginador.jsp?docTP=AC\&doclD=605411> Acesso em: 12 out. 2015.

6.

Disponível

em:

$<$ http://www.tjrj.jus.br/scripts/weblink.mgw?MGWLPN=JURIS\&LAB=CONxWEB\&PO RTAL $=1 \& P O R T A L=1 \& P G M=W E B P C N U 88 \& N=200300135646 \&$ Consulta $=\& C N J=01$ 19701-79.2002.8.19.0001>. Acesso em: 27 set. 2015.

7.

$<$ http://www.stj.jus.br/sites/STJ/default/pt_BR/noticias/noticias/Quarta-Turmamant\%C3\%A9m-condena\%C3\%A7\%C3\%A3o-de-Rafinha-Bastos-a-indenizarWanessa-Camargo>. Acesso em: 04 out. 2015. 
8. Disponível em: <http://www.planalto.gov.br/ccivil_03/_ato20112014/2012/lei//12737.htm>. Acesso em: 05 out. 2015.

9. Disponível em: <http://www.planalto.gov.br/ccivil_03/leis/2002/L10406.html>. Acesso em: 05 out. 2015.

10. Disponível em: <http://stj.jusbrasil.com.br/jurisprudencia/8584070/recursoespecial-resp-764735-rs-2005-0110506-4/inteiro-teor-13671997>. Acesso em: 01 out. 2015.

11.

Disponível

em:

$<$ https://ww2.stj.jus.br/websecstj/cgi/revista/REJ.cgi/ATC?seq=4291616\&tipo=51\&nre $g=200801875678 \&$ SeqCgrmaSessao $=\&$ CodOrgaoJgdr $=\& d t=20081118 \&$ formato=PD F\&salvar=false>. Acesso em: 02 out. 2015.

12. Disponível em: <http://stf.jusbrasil.com.br/jurisprudencia/774207/recursoextraordinario-re-215984-rj>. Acesso em: 01 out. 2015.

13. Disponível em: http://tj-sp.jusbrasil.com.br/jurisprudencia/23019155/apelacao-apl16190720118260510 -sp-0001619-0720118260510-tjsp/inteiro-teor-111201965.

Acesso: 30 set. 2015.

14.

<http://www.planalto.gov.br/ccivil_03/Constituicao/Constituicao.htm>. Acesso em: 02 out. 2015.

15. Tradução: o fato de expor uma pessoa contra a vontade pode dar inicio a uma compensação.

Enviado: Janeiro, 2020.

Aprovado: Janeiro, 2020. 